\title{
The Influence of Nutrition on Blood Sugar Level in Diabetus Millitus Type 2
}

\author{
$1^{\text {st }}$ Umi Faridah \\ Health Faculty \\ Universitas Muhammadiyah Kudus \\ Kudus, Indonesia \\ umifaridah@umkudus.ac.id
}

\author{
$2^{\text {nd }}$ Supardi \\ Health Faculty \\ Universitas Muhammadiyah Kudus \\ Kudus, Indonesia
}

\author{
$3^{\text {rd }}$ Ahmad Samsudin \\ Health Faculty \\ Universitas Muhammadiyah Kudus \\ Kudus, Indonesia
}

\begin{abstract}
One effort to control blood sugar levels is to diet. Strict diet of carbohydrates is not recommended for people with diabetes, because carbohydrates are a source of various nutrients including fiber, minerals, and vitamins that dissolve in water as well as a primary source of energy for the brain and central nervous system. Fiber that has a protective effect is high in vegetables and fruits. Rice is a food derived from processed rice plants, Rice contains high nutritional value of carbohydrate content of 360 calories, 6.8 grams of protein, and mineral content such as calcium and iron respectively 6 and $0.8 \mathrm{mg}$ and a little vitamin B2. Purpose: This study aims to determine the effect of nutrition on the normalcy of blood sugar when the patient diabetus millitus type 2 in Puskesmas Karang Rayung II Grobogan District. Method: The research method used is pre experiment with One-Group Pretest-posttest Design. The sample of research is 20 people. Data analysis using Paired Sample T-test. Result: The results showed that there was a statistically significant difference in mean Blood Sugar Level (KGD) when the type II DM patients between before and after were given nutrition in the form of daily rice intake $(\rho=0,000, t$ count $=0.534)$. Conclusion: The conclusion that can be taken is the consumption of nutrients in the form of rice with the right diet can affect the decrease in Blood Sugar Levels in patients with type II diabetes mellitus.
\end{abstract} 2

Keywords-Nutrition, Blood Sugar, Diabetus Millitus Type

\section{INTRODUCTION}

World Health Organization (WHO) in 2000 predicted an increase in the number of people with DM who became one of the global health threats. WHO predicts an increase in the number of people with DM in Indonesia from 8.4 million in 2000 to around 21.3 million in 2030. This report shows an increase in the number of people with DM as much as 2-3 times in 2035. While the International Diabetes Federation (IDF) predicts an increase in the number of people with DM in Indonesia from 9.1 million in 2014 to 14.1 million in 2035. (Indonesian Endocrinology Association, 2015).

The 2013 Basic Health Research (Riskesdas) report by the Ministry of Health shows that the number of insulin dependent DM cases in Central Java Province in 2013 was
9,376 cases, lower than in $2012(19,493)$. The highest cases are in Brebes Regency and Semarang City (1,095 cases). While the number of cases of insulin independent of DM is better known as type II DM, decreased from 181,543 cases to 42,925 cases. DM cases were not insulin dependent in the city of Surakarta (22,534 cases).

In several previous studies, it was noted that $50-80 \%$ of patients with DM had insufficient knowledge and skills in managing their diet or nutrition. Nutrition management needs to be done by people with deabitus mellitus so that their blood glucose is controlled and reduces the risk of complications. In these conditions knowledge about managing nutrition in the disease of deabitus mellitus is very important for patients so that dietary regulation becomes more effective. A specific study revealed that $75 \%$ of patients with deabitus mellitus disobeyed the recommended diet. Related research that has been done at Cengkareng Regional Hospital almost $50 \%$ of patients suffering from DM due to irregular eating patterns so that the patient's blood sugar rises and requires hospitalization and the rest due to ignorance about the disease (Pusparani, 2010).

Food planning (diet) is a basic management of type II DM before the use of oral hypoglycemic drugs or insulin injections. This management is better than the use of drugs, because it avoids the consumption of chemicals contained in the drug. In this diet, people with DM must really adjust their diet. DM sufferers must consume foods that are low in fat; enough carbohydrates; protein; high in fiber, especially soluble fiber found in vegetables and fruits (> 25 grams of soluble fiber / day) (Pusparani, 2010). Soluble fiber and other substances can be found in a variety of vegetables and fruits, such as kale, carrots, eggplants, cabbage, spinach, beans, red apples, star fruit, green pears, red guava, papaya, and so on. In addition to vegetables and fruits that have been mentioned, it turns out there is one plant that contains lots of fiber and antioxidants. The plant in question is a rosella plant that often grows in the yard of the house today. 
It's just that people are not aware of the various kinds of benefits contained therein (Kustyawati \& Ramli, 2008).

Deabitus Melitus patients in Karangrayung II Public Health Center in Gerobogan Regency are increasing from year to year. The number of deabitus mellitus patients in 2014 was 120 patients and 5 prolanis patients with uncontrolled blood sugar control, in 2015 there were 220 patients and 10 prolanis patients with uncontrolled blood sugar control, and in 2016 increased again by 480 patients with 14 patients with prolanis with uncontrolled blood sugar control. Characterized by black patches appearing on the skin (Medical Record Data in Karangrayung II Health Center, 2016).

Based on the description above, researchers are interested in conducting research on how the effect of nutrition on normal blood sugar when clients have type 2 diabetes mellitus at Karangrayung II Health Center, Grobogan Regency.

\section{METHOD}

This study used a pre-experimental design with a prepost test design in one group (One-Group Pretest-posttest Design). In one group pretest-posttest design is to measure what happens in the experimental group in accordance with the initial conditions before the experiment (pretest) and the differences that appear at the end of the experiment (posttest) without a control group.

The population in this study were patients with type 2 diabetes at Karangrayung II Grobogan Public Health Center, with a population of 30 people. Researchers get a sample of 20 people. This study uses "purposive sampling", namely sampling with certain considerations made by the researchers themselves, based on the characteristics or characteristics of the population that have been known previously. The analysis used in this study was paired t-test.

\section{RESULT AND DISCUSSION}

Blood sugar levels (KGD) When patients with type II DM before (pretest) are given nutrition food intake in the form of rice in the Karangrayung II Health Center Work Area of Grobogan Regency in 2017.

Univariate analysis in the form of blood sugar levels (KGD) when in patients with type II DM in Karangrayung II Puskesmas Work Area Grobogan Regency before (Pretest) was given food intake in the form of rice can be seen in table

TABLE I. DISTRIBUTION KGD FREQUENCY WHEN PATIENTS WITH TYPE II DM BEFORE (PRETEST) NUTRITION FOOD INTAKE IN THE FORM OF RICE IN THE KARANGRAYUNG IIBHEALTH CENTER WORK AREABGROBOGAN REGENCY IN 2017.

\begin{tabular}{|c|c|c|c|c|c|c|}
\hline $\begin{array}{c}\text { KGD } \\
\text { Sewaktu }\end{array}$ & N & Mean & Medaian & Sd & Min & Max \\
\hline Pretest & 20 & 293,75 & 229,00 & 88,034 & 122 & 477 \\
\hline
\end{tabular}

Based on table above it can be explained that the results of univariate analysis of KGD variables when in patients with type II DM before (Pretest) were given food nutrition in the form of rice in the Karangrayung II Health Center Work Area in 2017 had an average (Mean) KGD When $293.75 \mathrm{mg} / \mathrm{dl}$.

Blood sugar levels (KGD) When patients with type II DM after (posttest) were given nutritional food intake in the form of rice in the Karangrayung II Public Health Center in Grobogan Regency in 2017.

Univariate analysis in the form of blood sugar levels (KGD) when in patients with type II DM in Karangrayung II Puskesmas Work Area Grobogan Regency after (posttest) was given nutrition food intake in the form of rice can be seen in the table.

TABLE II. DISTRIBUTION OF KGD FREQUENCY WHEN PATIENTS WITH TYPE II DM POSTTEST NUTRIENT FOOD INTAKE IN THE FORM OF RICE IN KARANGRAYUNG II PUSKESMAS WORK AREA GROBOGAN REGENCY IN 2017.

\begin{tabular}{|c|c|c|c|c|c|c|}
\hline $\begin{array}{c}\text { KGD } \\
\text { Sewaktu }\end{array}$ & N & Mean & Medaian & Sd & Min & Max \\
\hline Posttest & 20 & 242,65 & 235,50 & 70,207 & 125 & 384 \\
\hline
\end{tabular}

Based on table above it can be explained that the results of univariate analysis of variable KGD when in patients with type II DM after (Posttest) were given nutrition food intake in the form of rice in the Karangrayung II Puskesmas working area in $2017 \mathrm{had}$ an average KGD at $242.65 \mathrm{mg} /$ dl.

\section{A. Bivariate Analysis \\ 1. Normality Test}

The normality test is a prerequisite in the parametric test. This test is used to determine whether the sample population is normally distributed or not. This test is usually used to measure data on an ordinal scale, interval or ratio.

In this study using the Kolmogorov-Smirnov one sample normality test. Test criteria is that if the significance value (p)> 0.05 then the data is normally distributed. The results of the normality test in this study can be seen in table below. 
TABEL III. HASIL UJI NORMALITAS DENGAN MENGGUNAKAN KOLMOGOROV-SMIRNOV

\begin{tabular}{|c|c|c|c|}
\hline Kadar Gula Darah (KGD) Sewaktu & $\rho$ & $\alpha$ & Keterangan \\
\hline KGD Sewaktu Pretest & 0,757 & 0,05 & Normal \\
\hline KGD Sewaktu Posttest & 0,841 & 0,05 & Normal \\
\hline
\end{tabular}

Based on table 4.6 it can be seen that the results obtained for the significance value for the two data groups are> 0.05 . Thus it can be concluded that the distribution of the two data groups is normal.

2. Differences in KGD When patients with type II DM between before (Pretest) and after (Posttest) are given food intake nutrition in the form of rice in Karangrayung II Puskesmas Work Area Grobogan Regency in 2017.

TABEL IV. DIFFERENCES IN THE AVERAGE KGD WHEN IN PATIENTS WITH TYPE II DM BETWEEN BEFORE (PRETEST) AND AFTER (POSTTEST) GIVEN INTERVENTION NUTRITION FOOD INTAKE IN THE FORM OF RICE IN THE WORKING AREA OF KARANGRAYUNG II HEALTH CENTER, GROBOGAN REGENCY, 2017.

\begin{tabular}{|c|c|c|c|c|c|c|}
\hline Variabel & $\mathrm{N}$ & Mean & $\begin{array}{c}\text { Standar } \\
\text { Deviasi }\end{array}$ & $\begin{array}{c}\text { Standar } \\
\text { Error }\end{array}$ & t hitung & $\rho v$ \\
\hline $\begin{array}{c}\text { KGD Sewaktu } \\
\text { Pre-Post }\end{array}$ & 20 & 51,10 & 17,827 & 3,986 & 0,534 & 0,000 \\
\hline
\end{tabular}

It can be seen that in Table 4.7 shows the mean (Mean) reduction of KGD When in patients with type II DM of $51.10 \mathrm{mg} / \mathrm{dl}$, and it can be concluded that there is a difference in mean (Mean) KGD When before and after being given nutrition food intake in the form of rice.

Statistical test results obtained $\rho v=0.000(\alpha=0.05)$, which means $\rho v$ is smaller than $\alpha$. As for the test calculation, there is a result that $\mathrm{t}$ arithmetic is 0.534 . Furthermore, the results of $\mathrm{t}$ arithmetic compared with $\mathrm{t}$ table, where the $\mathrm{t}$ table uses degrees of freedom $(\mathrm{df}=\mathrm{db}=$ $\mathrm{dk})=\mathrm{n}-1=20-1=19$. $\mathrm{T}$ table obtained is 0.444 , while $\mathrm{t}$ count obtained is 0.534 . From this comparison it can be seen that $\mathrm{t}$ arithmetic is greater than $\mathrm{t}$ table, which means that statistically is Ho is rejected or $\mathrm{Ha}$ is accepted. Means there is a difference in mean (Mean) KGD When statistically before and after being given food intake in the form of rice.

\section{B. Discussion}

Differences in Blood Sugar Level (KGD) When in patients with type II DM between before and after being given nutrition food intake in the form of rice in Karangrayung II Health Center Work Area Grobogan Regency in 2017.

KGD When (pretest) nutrition is given food intake in the form of rice has an average KGD When $293.75 \mathrm{mg} / \mathrm{dl}$, while KGD When (posttest) nutrition is given food intake in the form of rice has an average KGD When $242.65 \mathrm{mg} /$ dl. Based on the results of the study in table 4.4 it is known that there is an average decrease of KGD when in patients with type II DM of $51.10 \mathrm{mg} / \mathrm{dl}$, pv value between KGD when in patients with type II DM before (pretest) and after (posttest) of 0,000 (the value of pv $<>$ pv and $t$ arithmetic shows there is a statistically significant difference between
Bivariate analysis in this study was conducted to prove the hypothesis that had been made previously, so that it can be seen the effect of nutritional intake of food intake in the form of rice to decrease blood sugar levels in patients with type II DM in Karangrayung II Puskesmas working area in Grobogan Regency 2017. The results of the complete bivariate analysis can seen in table 4.7 .
KGD. Before (pretest) and after (posttest) nutritional intake of food intake in the form of rice.

There is a decrease in KGD Between before (pretest) and after (posttest) due to the treatment given, that is prior to the posttest, patients with type II DM have consumed food intake in the form of rice for 1 month. The results of the study were not much different from the study which explained that rosella tea water can reduce blood sugar levels in mice. Research by Arifiyani (2009) with the title Effect of Rosella Poached Water on Blood Glucose Levels in Experimental Studies in Mice with Glucose Loading. From the research, Arifiyani revealed that what had an effect on reducing blood sugar levels was the presence of flavonoids that were quite high. These flavonoids act as antioxidants, according to Haryadi (2017) antioxidants work to help neutralize free radicals that cause damage to pancreatic beta cells that produce insulin, thereby increasing insulin sensitivity again.

According to Prawiro (2009), KGD When high in patients with type II DM is controlled by several factors, namely sports / mild physical activity, diet / eating patterns, age, stress and education. Lack of

exercise / mild physical activity in patients with type II DM can cause increased insulin resistance in the body. Where the pancreas still produces insulin but the body is unable to use insulin effectively, resulting in an increase in blood sugar levels (hyperglycemia).

The second factor controlling KGD is diet / diet. Saturated fat intake, lots and types of carbohydrates consumed very greatly affect high levels of sugar in the blood. The recommended fat intake according to Perkeni (2011) in Shahab (2006) is 20-25\% of total calories. 
Carbohydrate consumption also greatly influences the increase in blood sugar levels. However, a strict carbohydrate diet is not recommended, because by avoiding carbohydrates completely cannot make blood sugar levels normal. Which affects

the increase in blood sugar levels is the type and amount of carbohydrates consumed.

\section{CONCLUSION}

There is a difference in mean (Mean) KGD When before and after being given nutrition food intake in the form of rice. Statistical test results obtained $\rho v=0.000(\alpha=0.05)$, which means $\rho v$ is smaller than $\alpha$. As for the test calculation, there is a result that $\mathrm{t}$ arithmetic is 0.534 .

\section{ACKNOWLEDGMENT}

I would like to thank to Muhammadiyah University of Kudus for both material and financial support for completing this research.

\section{REFERENCES}

[1] Baradero, Mary. (2009). Seri Asuhan Keperawatan Klien Gangguan Endokrin. Jakarta: EGC.

[2] Billous, R., \& Donelly, R. (2015). Buku Pegangan Diabetes, Edisi 4. Jakarta: Bumi Merdika.

[3] Corwin, Elizabeth J. (2009). Buku Saku: Patofisiologi Alih Bahasa Nike Budi Subekti, Jakarta : EGC.

[4] Kemenkes, 2013. Pusat Data dan Informasi. Jakarta Selatan.

[5] Kustyowati dan Ramli. 2008. Pemanfaatan tanaman hias rosela sebagai bahan minuman

[6] Notoatmodjo, 2012. MetodologiPenelitianKesehatan. Jakarta: RinekaCipta

[7] Pakjal, C. (2013). Ulkus Diabetikum. Pakjalpidie.blogspot.com.Ulkus Diabetikum.html.

[8] Pencegahan, P. D. A. N., \& Indonesia, D. I. (2015). Pengelolaan dan pencegahan diabetes melitus tipe 2 di indonesia 2015.

[9] PERKENI. (2011). Konsesus Pengelolaan dan Pencegahan Diabetes Melitus Tipe II di Indonesia. Jakarta.

[10] PERKENI. (2015).Konsensus Pengelolaan dan pencegahan Diabetes Melitus Tipe II Di Indonesia, JAKARTA

[11] Puspa Rani Lilis.(2010).Pengaruh pemberian teh rosela terhadap penurunan kadar gula darah (KGD) Sewaktu Pada penderita Diabetes Melitus Type II diwilayah Kerja Purkesmas Adpati I.Kab Cilacap STIKES Al Irsyat Al islamiah Cilacap

[12] Rangga Aji Nur Wahid (2016). Pengaruh Pendidikan Kesehatan Diabetes Self Management Education (DSME) Terhadap Kadar Gula Darah Pasien Diabetes Tipe II di Prolanis Puskesmas Gajahan Surakarta. 48

[13] Sutrisno Hadi, 2010. Metodologi Research. Yogyakarta: Andi.

[14] Sugiyono, 2013. Metode Penelitian Kuantitatif, Kualitatif. Bandung: Alfabeta.

[15] Suyono. (2004). Kecenderungan Peningkatan Jumlah Penyandang Daibetes, Soegondo, Soewondo, dan Subekti (eds). Penatalaksanaan Diabetes Millitus Terpadu, Pusat Diabetes Millitus Terpadu, Pusat Diabetes dan Lipid RSUP. Nasional Cipto Mangunkusumo-FKUI, Jakarta.

[16] Waspadji. (2004). Diabetes Melitus Mekanisme Dasar dan Pengelolaanya Yang Rasional, Dalam Soegondo, Soewondo, dan Subekti (eds). Penatalaksanaan Deabetus Militus Terpadu, Pusat Deabetus Militus Terpadu, Pusat dan Lipid RSUP Nasional Cipto Mangunkusumo-FKUI, Jakarta.

[17] Wesli Layuhibu (2015). Pengaruh Discharge Planning Terhadap Pengetahuan Pengelolaan Nutrisi Pasien Diabetes Mellitus Tipe II Di Rumah Sakit Muhammadiyah Yogyakarta. 